4. Третько В. В. Професійна підготовка магістрів міжнародних відносин у Великій Британії: теорія і практика : моногр. Хмельницький : ХНУ, 2013. 414 c.

5. A Community of Colleagues. Foreign Affairs, July/August 2015. July/August 2015 | Foreign Affairs: https://www.foreignaffairs.com/issues/2015/94/4.

6. Association of Professional Schools of International Affairs, APSIA: www.apsia.org.

7. Canadian Institute of International Affairs. (2014). Retrieved from http://www.thecanadianencyclopedia.ca/en/article/canadian-institute-of-international-affairs/

8. International Studies Association. Retrieved from http://www.isanet.org/ISA/Regions/Canada.

9. Official site of School of International Service: http://www.american.edu

10. Official site of The Association of Professional Schools of International Affairs: http://www.apsia.org.

11. Official site of The Fletcher School of International Affairs: http://fletcher.tufts.edu.

\title{
References
}

1. Bidiuk N., Tarasova O. Retrospektyvnyi ohliad rozvytku osvitnoho napriamu "Mizhnarodni vidnosyny" yak skladovoi humanitarnoi osvity u SShA. Pedahohika i psykholohiia profesiinoi osvity, 2013. Ch. 2. S. 242-253.

2. Istomina K. Yu. Profesiina pidhotovka fakhivtsiv z mizhnarodnykh vidnosyn: dosvid Kanady: monohr. Lviv : Vyd-vo Lviv. politekh., 2016. $124 \mathrm{~s}$.

3. Tarasova O. . Profesiina pidhotovka fakhivtsiv-mizhnarodnykiv u vyshchykh navchalnykh zakladakh SShA. Porivnialna profesiina pedahohika. 2011. № 1. S. 89-96.

4. Tretko V. V. Profesiina pidhotovka mahistriv mizhnarodnykh vidnosyn u Velykii Brytanii: teoriia i praktyka : monohr. Khmelnytskyi : KhNU, 2013.414 s.

5. A Community of Colleagues. Foreign Affairs, July/August 2015. July/August 2015 | Foreign Affairs. Retrieved from: https://www.foreignaffairs.com/issues/2015/94/4.

6. Association of Professional Schools of International Affairs, APSIA: www.apsia.org.

7. Canadian Institute of International Affairs. (2014). Retrieved from http://www.thecanadianencyclopedia.ca/en/article/canadian-institute-of-international-affairs/

8. International Studies Association. Retrieved from $\mathrm{http}: / / \mathrm{www}$.isanet.org/ISA/Regions/Canada.

9. Official site of School of International Service. Retrieved from: http://www.american.edu

10. Official site of The Association of Professional Schools of International Affairs. Retrieved from: http://www.apsia.org.

11. Official site of The Fletcher School of International Affairs. Retrieved from: http://fletcher.tufts.edu.

Одержано статтю: 25.01.2019

Прийнято до друку: 27.02.2019

УДК:378:373.2/.3.091.12.011.3-

051: 81 '243]:005.336.5

DOI: $10.15330 /$ esu. $15.31-38$
Ольга Лобода,

старший викладач, Київський університет імені Бориса Грінченка (м. Київ, Україна)

Olga Loboda,

Senior lecture, Kyiv Borys

Grinchenko University (Kyiv, Ukraine)

o.loboda@kubg.edu.ua

\section{ВПРОВАДЖЕННЯ ПОЗИТИВНОГО ДОСВІДУ ІНШОМОВНОЇ ПІДГОТОВКИ ПЕДАГОГІВ УГОРЩИНИ В УМОВАХ СВРОІНТЕГРАЦІЙНИХ ПРОЦЕСІВ В УКРАїHI}

\section{IMPLEMENTATION OF POSITIVE EXPERIENCE OF HUNGARIAN FOREIGN TRAINING OF PEDAGOGUES IN THE CONDITIONS OF THE EUROPEAN INTEGRATION OF UKRAINE}

У статті виокремлено позитивний досвід іниомовної підготовки педагогів Угориини. Розкрито особливості раннього навчання іноземної мови домкільної $i$ початкової ланок освіти. Схарактеризовано роль Проекту Багатомовна Свропа з питань 
сприяння вивченню іноземних мов, розробчі нових підходів до мовной підготовки та мовного навчання. Визначено роль іноземной мови і ї особливого значення в повсякденному житті Свропейського Союзу. Висвітлено схожі та відміниі аспекти підготовки вчителів іноземної мови в Украӥні та Угорицні. Визначено пріоритетні завдання іниомовної підготовки педагогів Украӥни, а саме: вдосконалення системи відбору даної категорії молоді для оволодіния педагогічною професісю, профоріснтачійна робота та розвиток особистісних якостей майбутніх вчителів іноземной мови.

Ключові слова: англійська мова; бакалавр; Британська Рада, доикільний вік; Європейська кончепџія вищой освіти; Європейський Союз; іншомовна підготовка; іноземна мова; магістр; молодиий икільний вік; підходи до мовной підготовки; позитивний досвід; Проект Багатомовна Європа; професійна підготовка; система підготовки педагогів; Угорицин; Україна.

At the present stage of development of society, the teaching of foreign languages plays a special role in the formation of a highly culturally and competitive personality capable not only successfully pursuing the search for the necessary information, but also realizing their social and professional mobility through intercultural communication. Integration of Ukraine into the European education space requires the expansion of foreign language professional skills of future specialists in the pre-and primary school education units.

The article outlines the positive experience of foreign language training of teachers in Hungary. It reveals the features of early language instruction in preschool and elementary school education. It characterizes the role of the Multilingual Europe Project on the promotion of the study of foreign languages, the development of new approaches to language learning and language learning. It determines the role of another language and its peculiarities in the current life of the European Union. The similar and different aspects of preparation of foreign language teachers in Ukraine and Hungary highlights. The priority tasks of foreign language training of Ukrainian teachers are determined, namely: improvement of the system of selection of this category of youth for mastering the pedagogical profession, vocational guidance work and the development of their personal qualities. The article deals with the strategic goals of pedagogical education and necessary changes of personality traits and professional competencies, which is both a goal and means of preparing students for future professional activities.

The author emphasizes that common to Ukraine and Hungary is the desire to form a system of pedagogical education, combining national traditions with progressive ideas of foreign experience, therefor, the study of the historical experience of organizing Hungarian teacher training provides the opportunity to highlights the best in order to implementation these ideas into practice in educational institutions of Ukraine and the main focus of the university should be directed at the development of the student's personality.

Key words: bachelor; British Council; European Union; foreign language training; foreign Language; Hungary; Master of Arts; Multilingual Europe Project; primary school age; approaches to language training; positive experience; preschool age; professional training; the system of teachers training; The European Concept of Higher Education; Ukraine.

Актуальність. Інтеграція України в європейське освітнє середовище, розширення та поглиблення міжнародних відносин потребує підвищення рівня володіння іноземними мовами та вимог до іншомовної підготовки висококваліфікованих фахівців дошкільної і початкової ланок освіти. Особливої уваги заслуговує вивчення кращого досвіду професійної підготовки вчителів до раннього іншомовного навчання у такій країні як Угорщина, яка не так давно приєдналася до Свропейського Союзу i, яка має багато спільних рис, включаючи і спільні кордони 3 Україною.

Аналіз наукових досліджень. В останнє десятиріччя вітчизняними вченими активно здійснюються дослідження в освітній галузі різних країн світу (Н. Абаш- 
кіна, Г. Андрущак, С. Власенко, В. Жуковський, Н. Заїченко, Л. Зязюн, К. Корсак, М. Лещенко, В. Полішук та ін.). Фаховий інтерес у наукових пошуках визначає зарубіжний досвід підготовки педагогічних кадрів Л. Пуховська, В. Гаманюк, К. Годлевська, М. Красовицький, А. Паринова, А. Вільчковська, Н. Карпенко та ін.). Питання навчання іноземних мов у країнах Європи розгляддають українські науковці В. Деркач, С. Гапонова, Л. Заблоцька, О. Кашуба, О. Котенко, О. Кузнєцова, Н. Лавриченко, М. Леврінц, О. Локшина, М. Олійник, В. Папіжук, О. Першукова, Л. Пуховська, В. Редько, М. Тадеєва. Проте окремі аспекти іншомовної підготовки фахівців у галузі дошкільної освіти висвітлені недостатньо.

Метою статті $\epsilon$ виокремити позитивний досвід іншомовної професійної підготовки фахівців у галузі дошкільної та початкової ланок освіти в Угорщині, а також особливості раннього навчання іноземної мови дітей дошкільного і молодшого шкільного віку з метою імплементації в Україні.

Виклад основного матеріалу. На сучасному етапі розвитку суспільства навчання іноземних мов відіграє особливу роль у формуванні висококультурної i конкурентоспроможної особистості, здатної не тільки успішно здійснювати пошук потрібної інформації, а й реалізовувати свою соціальну і професійну мобільність завдяки міжкультурному спілкуванню. Інтеграція України до європейського освітнього простору потребує розширення діапазону іншомовних професійних умінь майбутніх фахівців дошкільної і початкової ланок освіти.

Концептуальні засади розвитку педагогічної освіти та входження України в Європейський освітній простір регулюється законодавчою та нормативноправовою базою: законів України "Про освіту", "Про дошкільну освіту", “Про загальну середню освіту", "Про позашкільну освіту", "Про вищу освіту", Державна програма "Вчитель" тощо. Спільну основу для опрацювання програми професійної підготовки вчителів IM в Україні та Угорщині становлять Рекомендації Ради Європи [1].

У країнах Свропейського союзу накопичено багаторічний досвід підготовки педагогів до раннього навчання іноземних мов дітей дошкільного та молодшого шкільного віку, адже ще $з$ 90-х років XX ст.. у цих державах упроваджена програма раннього навчання іноземних мов. Так, Британською Радою, як міжнародною організацією Великої Британії, що сприяє розвитку культурних зв'язків, прагне до встановлення довгострокових відносин і довіри між людьми Великої Британії та інших країн створено Проект Багатомовна Свропа (БМС), що співфінансується Європейською Комісією і має на меті такі цілі: сприяти обміну успішним досвідом для забезпечення міжкультурного діалогу та соціальної інтеграції за допомогою мовної освіти; активізувати європейське співробітництво в галузі розроблення мовної політики і практики в декількох освітніх секторах, а також у суспільстві в цілому; підвищити поінформованість щодо рекомендацій Свросоюзу (EU) та Ради Свропи (Council of Europe) 3 питань сприяння вивченню іноземних мов та мовного розмаїття в Європі.

Однією із численних ініціатив з боку Ради Свропи та Європейського Союзу є розробка нових підходів до мовної підготовки та мовного навчання. Свою ініціативу Рада Європи втілила у публікаціях наступного характеру: the CEFR (Common European Framework of Reference: Learning, Teaching and Assessment), “Загальноєвропейські Рекомендації 3 мовної освіти: вивчення, викладання, оцінювання" (2001p.) та ELP (European Language Portfolio) "Свропейське мовне 
портфоліо", які представлені у вигляді інструментарію підтримки диверсифікації 3 питань оволодіння іноземною мовою.

У досліджуваній нами країні, а саме Угорщині, широкого розповсюдження набула Свропейська концепція вищої освіти. Утім, незважаючи на однакові у своїй більшості проблеми і стратегічні шляхи розвитку, кожна країна Свросоюзу має власний шлях реформування освіти. Зміни в системах освіти відбуваються під впливом сукупності зовнішніх чинників, серед яких домінантна роль належить економічним, політичним і соціокультурним.

Іноземні мови у системі дошкільної освіти Угорщини $\epsilon$ необов'язковими. Проте більшість дитсадків включають іноземну мову до навчальної програми. Той факт, що рік навчання у закладі дошкільної освіти в Угорщині є обов'язковим, гарантує, що більшість дітей ознайомиться з іноземною мовою до початку шкільної освіти. У багатьох закладах дошкільної освіти рішення щодо навчання дітей іноземної мови приймається на місцевому рівні i фінансується державою або за участі батьків. У системі початкової освіти вивчення однієї іноземної мови $\epsilon$ обов'язковим, при цьому школа вирішує, якої саме, хоча деякі школи дають дітям та їхнім батькам можливість обирати, яку мову вивчати [1, с. 31]. Зазначимо, що одна із цих мов (англійська, французька, німецька, італійська, російська) $\epsilon$ обов'язковою [1, с. 36].

У висновках ЄС (2002) наголошено на важливості вжиття заходів, спрямованих на те, щоб запропонувати учням початкової школи можливість вивчати з раннього віку дві або, в разі потреби, більшу кількість мов на додаток до їхньої рідної мови, а також на необхідності забезпечення якомога більшої розмаїтості мов. Окрім того, підкреслюється важливість формування засобами мовних програм позитивного ставлення до інших культур [1, с. 34].

Мови є невід'ємною частиною європейської ідентичності і найбільш прямим вираженням культури. В ЄС, заснованому на девізі "Єдність в різноманітті", здатність спілкуватися на декількох мовах $\epsilon$ важливою перевагою для окремих осіб, організацій і компаній. Мови не тільки відіграють ключову роль в повсякденному житті Європейського Союзу, але і мають фундаментальне значення для поваги культурного і мовного різноманіття в ЄС. ЄС підтримує два центри 3 вивчення мов: Європейський центр сучасних мов (ECML) i Європейський дослідницький центр з багатомовності та вивчення мов (Mercator). ECML сприяє вдосконаленню та інноваціям у викладанні мов і допомагає європейцям більш ефективно вивчати мови. Основними цілями ECML є допомога державам-членам в реалізації ефективної політики в галузі викладання мов шляхом зосередження уваги на вивченні і викладанні мов, сприяння діалогу та обміну передовим досвідом, а також підтримки програмних мереж і дослідницьких проектів. Mercator $\epsilon$ частиною мережі 3 п'яти дослідницьких i документальних центрів i спеціалізується на регіональні мови і мови меншин в Свропейському союзі [8].

Останнім часом в європейських країнах підготовка вчителів іноземних мов здійснюється закладами вищої освіти, оскільки країни послідовно реалізують політику забезпечення навчання іноземних мов на рівні вищої освіти. Так, у більшості країн передбачено вивчення студентами однієї, двох або більшої кількості іноземних мов незалежно від їхньої спеціалізації. Студентам відкрито доступ до факультативного вивчення іноземних мов, крім того багато навчальних закладів пропонують студентам курси з іноземних мов, результати навчання на яких не сертифікуються (non-accredited language courses). Оволодіти іноземними 
мовами студенти мають змогу на мовних відділеннях, у мовних центрах, в інших освітніх закладах, таких як Школи бізнесу чи економіки. У доповіді "Підготовка вчителів іноземних мов: розвиток у Європі" зазначено, що викладачі мов у вищих навчальних закладах зазвичай мають університетську освіту, утім мають недостатню підготовку 3 дидактики (general teaching) та методики викладання іноземних мов (language teaching) [7].

Щодо організації підготовки вчителів іноземних мов, слід вказати, що європейські країни в цілому здійснюють підготовку вчителів 330 іноземних мов, однак кількість мов, учителів з яких готують у різних країнах сильно варіюється. У всіх європейських країнах ведуть підготовку вчителів англійської, французької, німецької.

Модернізація структури вищої освіти України передбачає реалізацію підготовки вчителів IM за освітніми рівнями "базова вища освіта" та "повна вища освіта" з присудженням освітньо-кваліфікаційних рівнів бакалавра та магістра. У нашій країні тривалість підготовки вчителів IM на рівні бакалаврату становить 4 роки, незалежно від спеціалізації, на рівні магістратури - 1-2 роки, тоді як в Угорщині на рівні бакалаврату підготовка вчителя початкової школи та IM триває 4 роки, бакалавра мистецтв, філологів IM - 3 роки, а період навчання в магістратурі триває протягом 2-5 семестрів, після успішного завершення якої випускники одержують диплом вчителя IM [3, с. 29-130].

Одним із ключових елементів у галузі педагогічної освіти є забезпечення правильного поєднання теорії 3 практикою. Частка часу, що витрачається конкретно на професійну підготовку (професійне навчання), варіюється залежно від країни Європейського Союзу. У вищих навчальних закладах вищого рівня частка професійної підготовки, наприклад, для вчителів початкових класів варіюється від 13 до 70 \% із найвищим відсотком в Ірландії, Угорщині, Фінляндії, Словенії [4, с. 123$]$.

Одним із цільових завдань розвитку педагогічної освіти України $\epsilon$ вдосконалення системи відбору молоді для оволодіння педагогічною професією, зокрема спеціальністю вчителя IM. Як свідчить аналіз практики відбору абітурієнтів на навчання за напрямом підготовки “Освіта", спеціальність "Мова та література" (англійська мова, німецька мова тощо) у вищі навчальні заклади нашої країни, увага звертається, як правило, на рівень володіння IМ. В Україні, фактично, майже відсутня діагностика індивідуально-психологічних особливостей вступників, мотивації вибору педагогічної професії. На противагу, в Угорщині значна увага звертається на профорієнтаційну роботу з молоддю [2]. Проблема діагностики професійної придатності та професійного відбору майбутніх вчителів IM в Угорщині знайшла вирішення шляхом складання вступного іспиту до магістратури, головною метою якого є перевірка мотивації майбутніх вчителів IM та виявлення ціннісних орієнтацій, якими керуються абітуріснти, обираючи дану спеціальність [5, с. 130].

Профорієнтаційна робота зі студентами відділень IM відбувається в процесі вивчення практично зорієнтованих курсів методики навчання IM, психології та педагогіки, які покликані сформувати мотивацію студентів-вчителів IM. [5, с. 130].

Методична підготовка посідає важливе місце у системах педагогічної освіти України та Угорщини. У нашій країні розвиток методичної компетенції вчителя IM забезпечується за рахунок вивчення курсу методики навчання IM, методики проведення позашкільної та позакласної роботи [5, с. 132]. 
Суттєвою відмінністю між угорською та українською системами педагогічної освіти є необхідність складання комплексного іспиту в угорських ВНЗ is дисциплін психолого-педагогічного циклу та методики викладання IM до початку шкільної педпрактики. Студенти також проходять підготовку до та протягом педпрактики на основі спеціальних теоретично-практичних семінарів. Дуже важливим, на нашу думку, $є$ той факт, що надалі студенти закріплюються виключно за тими вчителями IM, які здобули кваліфікацію ментора - керівника шкільної педпрактики у системі післядипломної освіти Угорщини. В Україні ще не набула поширення практика підготовки вчителів до роботи зі студентамипрактикантами, тому не всі 3 них повністю готові до виконання функцій ментора (керівника практики) [5, с. 134].

Цікавим, на нашу думку, $\epsilon$ досвід поєднання додаткових педагогічних спеціалізацій в Угорщині. Студенти розпочинають навчання за обраними напрямами підготовки. Додаткову спеціалізацію вони обирають на власний розсуд, це може бути вчитель іноземної мови, виконання виховних обов'язків у спеціальних загальноосвітніх навчальних закладах, логопед, філософ, діловод (4/2013. (I. 11.). [9, c. 155]

Як зазначає К. Годлевська, сьогодні постала потреба змінити стратегічні цілі педагогічної освіти і змінити акценти із засвоєння спеціалістом формальних знань на розвиток його особистісних якостей та професійних компетентностей, що $\epsilon$ водночас i метою, i засобом підготовки студентів до майбутньої професійної діяльності. Очевидно, що в основу освітньої системи має бути покладений гуманістичний світогляд, який передбачає формування моральних принципів i якостей особистості - усвідомлення природи і людини у їх єдності, відмова від авторитарного стилю, уважне ставлення до цінностей, думок, вірувань інших людей (Чобітько, 2006). Тобто нині головна увага в навчально-виховному процесі ВНЗ скеровується на розвиток особистості студента [2, с 192].

Спільним для України та Угорщини $є$ прагнення сформувати систему педагогічної освіти, поєднуючи національні традиції 3 прогресивними ідеями зарубіжного досвіду, тому вивчення історичного досвіду організації угорської професійної підготовки вчителів надає можливість виділити найкраще 3 метою втілення цих ідей у практику в навчальних закладах України і головна увага ВНЗ скерована на розвиток особистості студента [9, с. 158].

Отже, як засвідчують дослідження науковців, угорська система освіти $€$ однією з найкращих у Європі. Реформування та доопрацювання навчальних планів гарантують їі конкурентоспроможність на європейському ринку освіти. Очевидною перевагою освітньої системи Угорщини вважають їі гнучкість [2, с. 124].

Висновок. Актуальність вивчення досвіду іншомовної підготовки майбутніх педагогів Угорщини має неабияке значення для України, яка впевнено крокує в європейський простір і впроваджує у навчальний процес ВНЗ освітні інновації. Нам імпонує діагностика індивідуально-психологічних особливостей вступників Угоршини i мотивація вибору ними педагогічної професії; подальша профоріснтаційна робота зі студентами та розвиток їх особистісних якостей i професійних компетентностей; складання вступного іспиту до магістратури, головною метою якого є перевірка мотивації майбутніх вчителів IM та виявлення ціннісних орієнтацій, якими керуються абітурієнти, обираючи дану спеціальність.

Подальшої наукової розробки потребує вивчення методичних систем, які притаманні дошкільній та початковій іншомовній освіті в Угоршині та порівняння 
змісту підготовки учителів іноземних мов для дошкільної та початкової ланок освіти.

\section{Література}

1. Багатомовна Європа: тенденції у політиці і практиці мультилінгвізму в Європі. - К. : Ленвіт, 2012. - $168 \mathrm{c}$.

2. Годлевська К. В. Професійна підготовка майбутніх учителів початкових класів. у коледжах та університетах Угорщини: дис. канд. пед. наук. : спец.: 13.00.04 "Теорія і методика професійної освіти" / Годлевська Катерина Василівна. - К. НАПНУ, 2017. - 322 с.

3. Козубовська I. В., М.І. Леврінц М.I. Порівняльний аналіз професійної підготовки майбутніх учителів іноземних мов в Україні та Угорщині. Порівняльна професійна педагогіка : наук. журнал / голов. ред. Н. М. Бідюк. - К.; Хмельницький : ХНУ, 2011. - Вип. 2. - 201 с.

4. Кристопчук Т.Є. Система педагогічної освіти в країнах Європейського Союзу: спільні та відмінні риси / Т.С. Кристопчук // Наукові праці. - Вип. 197, Том 209. Педагогіка - 2012. - С. 121-126.

5. Леврінц M.І., автореферат на здобуття наукового ступеня кандидата педагогічних наук "Формування мотивації допрофесійної педагогічної майбутніх фахівців іноземних мов в Угорщині”, Електронний ресурс] - режим доступу: https://www.google.com.ua/ search?q=Леврінц+M.I.\%2C+автореферат+на+здобуття+наукового+ступеня+кандидата+педа гогічних +наук+" "Формування+мотивації+допрофесійної+педагогічної+майбутніх $+ф а х і в ц і в+i$ ноземних +мов+в+У горщині" \&oq=Леврінц+М.І.\%2С

6. Ніколаєва С.Ю., Загальноєвропейські Рекомендації з мовної освіти: вивчення, викладання, оцінювання / [наук. ред. С. Ю. Ніколаєва]. - К. : Ленвіт, 2003. - 273 с.

7. Teacher Education in Europe An ETUCE Policy Paper. Adopted by the Executive Board on 14th April 2008 // Editor responsible at law: Martin Romer. - Published by the European Trade Union Committee for Education - Brussels, 2008. - 64 P.

8. Language policy | Fact sheets on the European Union URL: http://www.europarl.europa.eu/ factsheets/en/sheet/142/language-policy

9. Ящук І.П, Біницька К.М, Кузьма І.І. Порівняльний аналіз професійної підготовки майбутніх учителів початкової освіти в Румунії та Угорщині. / Ящук І.П., Біницька К.М., Кузьма I.I.// наук.-практ. журнал Наука і Педагогіка -2018. Випуск - 2. С. 153-160.

\section{References}

1. Baghatomovna Jevropa: tendenciji u polityci i praktyci muljtylinghvizmu v Jevropi (2012), Lenvit, $168 \mathrm{c}$.

2. Hodlevs'ka K. V. Profesijna pidhotovka majbutnikh uchyteliv pochatkovykh klasiv. u koledzhakh ta universytetakh Uhorschyny: dys. kand. ped. nauk. : spets.: 13.00.04 "Teoriia i metodyka profesijnoi osvity" / Hodlevs'ka Kateryna Vasylivna. - K. NAPNU, 2017. - 322 s.

3. Kozubovs'ka I. V., M.I. Levrints M.I. Porivnial'nyj analiz profesijnoi pidhotovky majbutnikh uchyteliv inozemnykh mov v Ukraini ta Uhorschyni. Porivnial'na profesijna pedahohika : nauk. zhurnal / holov. red. N. M. Bidiuk. - K.; Khmel'nyts'kyj : KhNU, 2011. - Vyp. 2. - 201 s.Osvita v Bolgariji. [Education in Bolgaria] [Elektronnyj resurs].- Rezhym dostupu: https://uk.wikipedia.org/wiki/\%D0\%9E\%D1\%81\%D0\%B2\%D1\%96\%D1\%82\%D0\%B0_\%D0\%B 2 2\%D0\%91\%D0\%BE\%D0\%BB\%D0\%B3\%D0\%B0\%D1\%80\%D1\%96\%D1\%97

4. Krystopchuk T.Ye. Systema pedahohichnoi osvity v krainakh Yevropejs'koho Soiuzu: spil'ni ta vidminni rysy / T.Ye. Krystopchuk // Naukovi pratsi. - Vyp. 197, Tom 209. Pedahohika - 2012. S. 121-126. Tadejeva M. Suchasni tendenciji rozvytku shkiljnoji inshomovnoji osvity v krajinakh chlenakh rady Jevropy (porivnjaljnyj analiz) [Contemporary trends in the development of school foreign education in the member countries of the Council of Europe (comparative analysis)], extended abstract of Doctor's thesis spec.13.00.01 "Zaghaljna pedaghoghika ta istorija pedaghoghiky" / M Tadejeva-Lughansjk, 2011, $40 \mathrm{~s}$.

5. Levrints M.I., avtoreferat na zdobuttia naukovoho stupenia kandydata pedahohichnykh nauk "Formuvannia motyvatsii doprofesijnoi pedahohichnoi majbutnikh fakhivtsiv inozemnykh mov v Uhorschyni", Elektronnyj resurs] - rezhym dostupu: https://www.google.com.ua/ search?q=Леврінц+М.I.\%2C+автореферат+на+здобуття+наукового+ступеня+кандидата+педа гогічних +наук+" "Формування+мотивації+допрофесійної+педагогічної + майбутніх + фахівців $+\mathbf{i}$ ноземних +мов + В + Угорщині" \&оq=Леврінц + М.I.\%2C

6. Nikolaieva S.Yu., Zahal'noievropejs'ki Rekomendatsii z movnoi osvity: vyvchennia, vykladannia, otsiniuvannia / [nauk. red. S. Yu. Nikolaieva]. - K. : Lenvit, 2003. - 273 s. 
7. Teacher Education in Europe An ETUCE Policy Paper. Adopted by the Executive Board on 14th April 2008 // Editor responsible at law: Martin Romer. - Published by the European Trade Union Committee for Education - Brussels, 2008. - 64 P.

8. Language policy | Fact sheets on the European Union URL: chttp://www.europarl.europa.eu/ factsheets/en/sheet/142/language-policy

9. Yaschuk I.P, Binyts'ka K.M, Kuz'ma I.I. Porivnial'nyj analiz profesijnoi pidhotovky majbutnikh uchyteliv pochatkovoi osvity v Rumunii ta Uhorschyni. / Yaschuk I.P., Binyts'ka K.M., Kuz'ma I.I.// nauk.-prakt. zhurnal Nauka i Pedahohika -2018. Vypusk - 2. S. 153-160.

Одержано статтю: 3.03 .2019

Прийнято до друку: 27.03.2019

УДК 37:364.65

DOI: $10.15330 /$ esu. $15.38-45$

\section{Ільдіко Орос,}

кандидат педагогічних наук,

Закарпатський угорський інститут

ім. Ференца Ракоці II (м. Берегово, Україна)

Ildiko Oros,

Candidate of pedagogical sciences,

Ferenc Rakoczi II Transcarpathian Hungarian

Institute (Beregovo, Ukraine)

ildiko@kmf.uz.ua

\section{КОНЦЕПТУАЛЬНІ ПЦДХОДИ ДО ОСВІТИ ДОРОСЛИХ В УКРАЇНІ}

\section{CONCEPTUAL APPROACHES TO ADULT EDUCATION IN UKRAINE}

Освіту дорослих розглядають як систему, покликану компенсувати недоліки загальноосвітньої і вищої иколи.

В Украӥні останнім часом видана низка кончепчій, у яких визначено основні завдання та мета розвитку освіти дорослих, приниипи, форми освіти, напрями реалізачіі кончепчії, передбачено й очікувані результати, піднімається питання обміну досвідом із різиими країнами щодо розвитку освіти дорослих; визначено чинники, які впливають на розвиток професійної освіти у XXI столітті, яка повинна задовольняти потреби держави у кваліфікованих кадрах і потреби особистості в якісній профосвіті.

3'ясовано зміст кончептуальних положень формування освітньої системи дорослих України та яку роль відіграють конџетиї у розвитку освіти дорослих в Украйні.

Ключові слова: концептуальні положення, освіта дорослих, Украйна, потреби держави, кваліфіковані кадри, освітня система дорослих.

Recently, a number of concepts have been published in Ukraine, in which the main tasks and goals of adult education development, principles, forms of education, directions of the concept implementation, anticipated and expected results are determined, the issue of the exchange of experience with different countries on the development of adult education is raised; The factors influencing the development of vocational education in the XXI century, which should meet the needs of the state in skilled personnel and the needs of the person in high-quality professional education, are determined.

In 2002, the concept of postgraduate education was approved by the Board of MES of Ukraine. In order to implement the national strategy for the development of education in Ukraine for the period up to 2021 the concept of the development of continuous pedagogical education was adopted, which defined the basic principles of the development of continuous pedagogical education (continuity, the combination of national educational traditions and best world experience, flexibility of response to social changes and predictability, innovation), the task of its development (improvement of the structure of postgraduate education, the direction of the development of continuous pedagogical education for modernization on all levels of education content, forms, methods and learning technologies as required informational civil 